\title{
STUDY PROGRAM PERFORMANCE IMPROVEMENT MODEL BY WAY OF PERFORMANCE MANAGEMENT SUPPORTED BY UTILIZATION OF INFORMATION TECHNOLOGY AND ORGANIZATIONAL CLIMATE IN UNIKOM
}

\author{
EDDY SOERYANTO SOEGOTO \\ Program Studi Manajemen, Fakultas Ekonomi dan Bisnis \\ Universitas Komputer Indonesia
}

The Performance of Study Program is the determinant factor of Higher Education performance. The decrease of the number of students enrolling in the Study Program (Prodi), the accreditation result of Prodi, the duration of student study and the absorption of alumni are the factors of Prodi performance that have not been achieved yet according to the purpose of the Institution. The problem is pointed out that only the utilization of information technology has not been evenly distributed both to lecturers and employees, to unorganized organizational climate, and performance management that has not been effectively implemented. Based on these phenomena, the purpose of this study is to obtain the results of the study and analysis of the study program performance model affected by management performance with the help of utilization of information technology and organizational climate.

Research approach is quantitative. The object of research is the study program in UNIKOM environment with saturated samples amounted to 27 Study Programs. Data collection uses questionnaires, interviews and documentation. The analysis procedure is path analysis.

Research result shows that the performance of study program in the UNIKOM environment has not been in accordance with institutional expectations, especially in the acquisition of accreditation; Performance management has not been effective yet; Utilization of information technology especially software implementation has not been conducive to service to students, and organization climate has not been fully support the achievement of Prodi's performance yet, especially in achieving superior accreditation. This research result generates a new model, which is different from the previous research, where the use of information technology, and organizational climate give very low direct effect to Prodi's performance, whereas the performance management shows dominant effect on Prodi's performance. This means that Prodi's performance will be optimal when it has the use of appropriate information technology and organizational climate conducive in supporting effective performance management.

Keywords : Performance of Study Program, Performance Management, Utilization of Information Technology, and Organizational Climate 


\section{PENDAHULUAN}

Setiap bidang ilmu mempunyai sejarah perkembangan yang khas dan menarik untuk dikaji. Persoalan-persoalan yang berkembang karena semangat jaman, perubahan-perubahan yang terjadi termasuk perkembangan teknologi mendorong munculnya kajian-kajian terhadap ilmu tersebut. Persoalan satu dapat diselesaikan muncul persoalan baru lagi. Kondisi ini menjadikan ilmu tersebut menjadi dinamis dan menantang untuk terus diteliti dan dikembangkan sesuai dengan perkembangan jaman. Memasuki abad teknologi infromasi, perubahan terjadi sangat cepat dalam semua aspek kehidupan manusia. Ketika suatu informasi baru muncul, maka dalam hitungan detik informasi tersebut akan tersebar keseluruh penjuru dunia. Manusia diterpa dengan berbagai informasi dengan begitu cepatnya tanpa daya untuk menghindar. Oleh karena itu diperlukan sarana yang tepat untuk menyaring informasi yang deras tersebut.

Di era penuh persaingan, dan perubahan teknologi informasi yang cepat serta perekonomian global, kebutuhan organisasi baik bisnis maupun non bisnis (public service's) yang terus meningkat untuk mengembangkan berbagai upaya meningkatkan perhatian pada customer, memberikan dorongan pada setiap organisasi untuk menjadi yang terbaik dalam mencapai tujuannya melalui organisasi yang berorientasi pada pelanggan (customer focus). Meskipun teknologi dapat membantu menciptakan orientasi pelanggan, namun pelayanan tetap merupakan masalah 'human'. Bagaimana seorang individu dibangkitkan inspirasinya, diberi kemampuan, dimotivasi, dan diakui oleh para pemimpin dan manajer merupakan faktor penting dalam upaya menciptakan perusahaan yang berorientasi kepada pelanggan.

Kelangsungan hidup seseorang akan bergantung pada kemampuannya untuk mengelola diri sendiri dan lingkungan secara efektif. Jika suatu perubahan juga menuntut perubahan penguasaan seseorang pada suatu bidang tertentu, hal tersebut dapat dianggap sebagai ancaman bagi kelangsungan hidup seseorang. Yang dimaksud penguasaan disini adalah berkenaan dengan keterampilan, kemampuan, pengetahuan dan lain sebagainya, sehingga peningkatan penguasaan kerja seseorang perlu dibarengi oleh pelatihan dan pendidikan profesional untuk mampu bertahan dalam suatu perubahan. (Eddy Soeryanto, 2016). Paling tidak, perlu dilakukan suatu dialog tentang dampak perubahan terhadap penguasaan profesional.

Penelitian sebelumnya yang pernah dilakukan oleh Mahn Hee Yoon, Sharon E. Beatty, Jaebeom Suh tahun 2001 berfokus terhadap dua komponen internal marketing yang sangat berpengaruh terhadap kemampuan suatu organisasi dalam implementasi pelayanan yang prima (service excellence) yaitu iklim kerja (work climate) dalam hal ini termasuk di dalamnya, iklim pelayanan (service climate) dan keberadaan manajemen yang mendukung (supportive management) dalam organisasi yang bersangkutan.

Perkembangan tersebut mendorong organisasi-organisasi bisnis untuk memiliki SDM handal dengan iklim organisasi yang kondusif dan memahami teknologi informasi untuk kepentingan pengelolaan organisasi mereka secara menyeluruh. Segaris dengan masalah tersebut suatu alternatif solusi ialah melakukan kegiatan riset yang berbasis pada sumber daya manusia dan fasilitas teknologi informasi di dalam organisasi-organisasi bisnis tersebut. Sebagai salah satu kontribusi perguruan tinggi dalam mengimplemnetasikan Tri Dharma Perguruan Tinggi, maka kajian ini dapat memberikan gambaran mengenai model manajemen sumber daya manusia yang berbasis pada teknologi informasi kepada dunia pendidikan dengan pertimbangan iklim organisasi yang merupakan faktor penting dalam 
perkembangan pendidikan di tanah air.

Perkembangan teknologi informasi yang sangat pesat diabad 21 ini telah membawa perubahan yang mendasar dalam segala sendi bermasyarakat, termasuk didalamnya penyebaran informasi keilmuan dan teknologi. UNIKOM (Universitas Komputer Bandung), salah satu PTS di kota Bandung, merupakan salah satu perguruan tinggi berbasis komputer yang menerapkan kewajiban mendapatkan ilmu pengetahuan berbasis komputer, meliputi aspek software, hardware dan aspek multimedianya. komputer pada setiap program studi. Hal ini dimaksudkan untuk menciptakan Sumber Daya Manusia yang ahli di bidangnya masing-masing dengan memiliki landasan ilmu komputer yang dimilikinya sehingga keterampilan komputer mampu mengantarkan kompetensi di bidangnya dalam menyikapi perkembangan dunia yang semakin berbasis teknologi informasi ini. Oleh karena itu, dalam memberikan jaminan qualitas dan quantitas terus diupayakan sesuai dengan motto yang di pegang teguh "Quality is Our Tradition". Pimpinan UNIKOM menyadari benar, selain keberadaan dosen, sumber daya manusia lain yang tak kalah pentingnya adalah para karyawan yang turut menentukan kualitas layanan UNIKOM baik kepada mahasiswa maupun stakehoder lainnya.

Secara bertahap dan berkesinambungan, untuk sarana prasarana terus ditingkatkan. Terbukti telah didirikan satu area gedung di jalan Dipati Ukur 102-108 dengan ketinggian 17 lantai. Tak kalah pentingnya, peningkatan kinerja karyawan terus diprioritasnta. Dengan student body mahasiswa sekitar 13.000 mahasiswa, dan dosen 312 orang serta karyawan berjumlah 188 maka peran keberadaan karyawan sangat penting untuk menampilkan unjuk kerja yang maksimal dalam fungsinya memberikan pelayanan kepada pihak-pihak internal maupun eksternal dengan pemanfaatan teknologi informasi dan iklim organisasi yang didukung oleh manajemen kinerja.

Kinerja Program studi di UNIKOM dirasakan belum maksimal sesuai target Prodi, terlihat jumlah mahasiswa diterima pada beberapa prodi tidak konsisten, mayoritas akreditasi program studi di UNIKOM masih 'B', bahkan masih ada satu program studi yang masih ' $C$ '. Tingkat ketepatan studi mahasiswa untuk prodi besar lebih dari 4 tahun, Sedangkan yang akreditasi 'A' hanya 4 dari 27 Program Studi yang ada di UNIKOM. Hal ini dipicu, oleh iklim organisasi yang dirasakan belum kondusif, dimana cara kerja dosen khususnya karyawan sangat tergantung pada pimpinan, inovasi kurang dan beberapa dosen dan karyawan merasa kurangnya kepedulian institusi terhadap pegawai. Walaupun secara keseluruhan Teknologi informasi terus dilakukan perbaikan-perbaikan secara menyeluruh, namun belum dapat diimplementasikan secara maksimal keberadaannya.

Penelitian ini bertujuan untuk menguji model kinerja program studi dengan dua rumusan penelitian, yaitu:

1. Apakah manajemen kinerja dibentuk melalui pemanfaatan teknologi informasi dan iklim organisasi baik secara simultan maupun parsial.

2. Apakah kinerja Program Studi ditentukan oleh manajemen kinerja yang didukung pemanfaatan teknologi informasi dan iklim organisasi baik secara langsung maupun tidak langsung.

Berdasarkan uraian di atas, maka dalam kajian penelitian ini penulis bertujuan memberikan informasi dan solusi :

Kinerja Program Studi, manajemen kinerja, pemanfaatan teknologi informasi dan iklim organisasi.

Ada tidaknya keterkaitan antara Kinerja Teknologi Informasi, iklim organisasi, dan Manajemen Kinerja serta Kinerja Program Studi.

Menghasilkan sebuah model Kinerja 
Organisasi yang dibangun melalui Manajemen Kinerja yang didukung oleh Pemanfaatan Teknologi Informasi dan iklim organisasi

\section{KAIIAN PUSTAKA}

\section{Pemanfaatan Teknologi Informasi}

Berkembangnya waktu membuat perusahaan atau organisasi semakin maju; maka hasil pekerjaan dituntut untuk tepat waktu, akurat dan sistematis. Dengan kata lain, produktivitas kerja tidak dapat hanya mengandalkan aspek ketrampilan dan pengorganisasian tetapi diperlukan juga aspek-aspek yang bersifat mekanistik. Pada tingkatan ini suatu perusahaan memasuki periodesasi teknologi dimana unsur-unsur teknologis diperlukan dalam mencapai produktivitas kerja yang tinggi. Salah satu sifat teknologi ialah tidak mempunyai tenggang rasa dan kadang bahkan tidak manusiawi karena teknologi lebih mementingkan akurasi dan ketepatan waktu yang pada akhirnya berdampak pada perubahan orientasi para karyawan.

Menurut Bagranof et. al (2010:8) yang dimaksud dengan teknologi informasi terdiri dari hardware, software, dan komponenkomponen sistem terkait yang digunakan oleh organisasi untuk membangun sistem informasi berbasis komputer. Sedangkan Menurut Turban dan Volinino (2011:8), teknologi informasi merupakan istilah yang dipakai untuk menjelaskan kumpulan dari sistem informasi organisasi, user, dan manajemen yang melakukan pengawasan/ pengaturan terhadap sistem informasi tersebut.

Menurut O' Brien (2009:7) komponen teknologi informasi meliputi: (1) computer, (2) hardware, software, (3) internet dan jaringan komunikasi lainnya, (4) teknikteknik manajemen sumberdaya data berbasis komputer (data base management), dan (5) teknologi-teknologi informasi berbasis komputer lainnya, sedangkan menurut
Weill (1998) bahwa infrastruktur teknologi informasi membantu dalam efektivitas operasi suatu organisasi dalam kaitannya dengan komunikasi, pelaporan, analisis, perencanaan, pengontrolan dan pembuatan keputusan. Sejalan dengan weill, Applegate et al (2009) dalam Dadang Munandar (2015) menggunakan istilah infrastruktur teknologi informasi untuk menjelaskan komponen-komponen dari teknologi informasi. Istilah "infrastruktur" teknologi informasi berarti: ... the entire layered fabric of hardware, software, systems, and media that collectively deliver IT Services.

Menurut Greaves et al., (1999) bahwa manfaat teknologi informasi bagi perusahaan adalah otomatisasi fungsi bisnis melalui pelayanan jaringan kepada konsumen dengan biaya yang lebih rendah, lebih responsif, dan potensi yang lebih besar untuk pelayanan konsumen. Sedangkan menurut Lederer et.al., (2001) Teknologi jaringan memberikan sejumlah manfaat informasi, sebagaimana bisnis menggunakan saluran internet untuk memberikan informasi tentang spesifikasi produk, harga, dan metoda penyampaian jasa. Manfaat khusus dari informasi antara lain: kualitas informasi, kemudahan akses informasi, dan kemampuan berbagi informasi.

\section{Pentingnya Iklim Organisasi}

Menurut Tagiuri dan Litwin dalam Wirawan (2007) iklim organisasi merupakan kualitas lingkungan internal organisasi yang secara relatif terus berlangsung, dialami oleh anggota organisasi, mempengaruhi perilaku mereka dan dapat dilukiskan dalam pengertian satu set karakteristik atau sifat organisasi. Stringer dalam Wirawan (2007) mendefinisikan iklim organisasi sebagai “...collection and pattern of enviromental determinant of aroused motivation." Iklim organisasi sebagai koleksi dan pola lingkungan yang menentukan munculnya motivasi. 
Mengacu pada pendapat Denison (1990), Plunket (2005), iklim organisasi merupakan kualitas lingkungan internal yang dipersepsi anggotanya. Suatu organisasi yang mampu menciptakan iklim organisasi yang berkualitas, akan mempengaruhi dan membentuk perilaku kerja anggota organisasi yang pada akhirnya berpengaruh pada kinerja organisasi.

James dan Jenoe dalam Simamora (2004) mengemukakan tiga pandangan tentang iklim organisasi, sebagai berikut :

a. Iklim organisasi sebagai sekumpulan ciri organisasi yang dapat diterangkan dengan obyektivitas yang masuk akal. Ciri-ciri ini membedakan organisasi tersebut dengan organisasi lainnya yang secara relatif bertahan dan mempengaruhi perilaku individu dalam organisasi tersebut.

b. Iklim sebagai konsep yang merefleksikan isi dan kelebihan dari nilai-nilai, norma, perilaku dan perasaan para anggota dan sebuah sistem sosial yang secara operasional dapat diukur melalui persepsi dari anggota-anggota sistem.

c. Iklim organisasi itu mempunyai sesuatu yang signifikan hanya pada setiap individu. Karena individu tersebut itulah yang terlibat atau tidak terlibat dalam keputusan-keputusan, mengalami atau tidak komunikasi yang efektif dan hangat, mempunyai otonoi atau tidak, dan sebagainya.

Iklim organisasi berhubungan erat dengan suasana atau atmosfer yang terdapat dalam organisasi itu sendiri (Dessler, 2013). Dalam hal ini iklim organisasi merupakan suatu variabel yang mempengaruhi kinerja individu dan organisasi sebagai efek dari proses organisasional dan psikologis. Iklim yang dirasakan positif oleh karyawan akan memunculkan perilaku yang inovatif yang muncul dari pemikiran-pemikiran baru yang tidak terkekang dan mendapatkan dukungan dari perusahaan. Selain itu, karyawan akan memiliki persepsi yang positif terhadap keberfungsian organisasi. Maka dari itu menciptakan iklim kreatif dalam sebuah organisasi menjadi sangat penting untuk mendukung dan menstimulasi kreativitas individu-individu di dalamnya.

Menurut Hoogendoorn (1999), indikator iklim organisasi dalam suatu perusahaan adalah: otonomi dan fleksibilitas, menaruh kepercayaan dan terbuka, simpatik dan memberi dukungan, jujur dan menghargai, kejelasan tujuan, pekerjaan yang berisiko, serta pertumbuhan kepribadian. Seorang pemimpin yang mampu bersikap simpatik akan dihormati karyawan, sehingga keputusan pemimpin tersebut juga dapat dihormati dan dilakukan oleh karyawan. Pemberian dukungan kepada karyawan dalam setiap pekerjaan juga akan menciptakan suasana atau iklim kerja yang baik.

Selaras dengan pengembangan iklim organisasi, iklim kerja yang positif merupakan suatu kondisi dimana keadaan perusahaan dan lingkungannya dalam keadaan aman, damai, dan menyenangkan untuk akivitas kerja pegawai. Sergiovanni dalam Mangkunegara (2004) berpendapat bahwa iklim secara umum diciptakan, dibentuk dan disalurkan sebagai hasil dari suatu kepemimpinan interpersonal yang efektif oleh pimpinan organisasi. Pada hakekatnya iklim bersifat interpersonal dan dimanifestasikan dalam sikap dan perilaku pimpinan, pegawai dalam kegiatan kerjanya. Selain itu, iklim merupakan energi yang terdapat di dalam organisasi yang dapat memberikan pengaruhnya terhadap organisasi, tergantung bagaimana energi tersebut di salurkan dan diarahkan oleh pimpinan organisasi. Semakin baik energi yang disalurkan dan diarahkan maka semakin baik pula pengaruhnya terhadap perusahaan.

Interaksi di dalam tempat kerja, baik yang lisan maupun yang tertulis mutlak diperlukan dan akan memberikan dampak proses dan hasil kerja yang positif. Kolb, et.al dalam Komariah dan Triatna (2005) 
mencatat 11 dimensi iklim organisasi yang dapat diadaptasikan bagi iklim kerja, yaitu : 1). Struktur tugas, 2). Hubungan imbalan hukum, 3). Sentralisasi keputusan, 4). Tekanan pada prestasi, 5). Tekanan pada latihan dan pengembangan, 6). Lingkungan kerja yang aman, kebersihan dan kelengkapan sarana prasarana, 7). Keterbukaan versus ketertutupan, 8). Rasa kekeluargaan 9). Pengakuan dan umpan balik, 10). Status dan semangat, 11).Kompetensi dan keluwesan organisasi.

\section{Peranan Manajemen Kinerja}

Manajemen kinerja pada umumnya dimaknai sebagai suatu proses yang bertujuan untuk memperbaiki kinerja organisasi. Dapat diartikan manajemen kinerja meliputi : performance management dan managing employee performance. Selanjutnya definisi program manajemen kinerja meliputi: (1) merencanakan, (2) proses manajemen, dan (3) produktivitas. Manajemen kinerja meliputi pengelolaan semua elemen proses organisasi yang mempengaruhi prestasi meliputi penetapan tujuan, seleksi \& penempatan pekerja, penilaian, kompensasi, pelatihan, dan manajemen karir.

Ruang Lingkup Program Manajeman Kinerja terdiri dari beberapa elemen: (a). Teknologi (Peralatan, metode kerja), (b). Kualitas dari input (termasuk material), (c). Kualitas lingkup fisik (keselamatan, kesehatan kerja), (d). Iklim dan budaya organisasi (termasuk supervisi dan kepemimpinan (e).
Sistem kompensasi dan imbalan. Manajemen kinerja meliputi: 1) Perencanaan kinerja (performance planning), 2) Penilaian kinerja (performance appraisal), 3. Umpan balik (feedback). Selanjutnya disebutkan oleh Mathis (2004) bahwa sistem manajemen kinerja yang efektif meliputi: Relevance, Sensitivity, Reliability, Acceptability dan Practicality.

\section{Kinerja Organisasi}

Menurut Huang, Binney dan Hede (2010: 4) kinerja kelembagaan yang terkait dengan keunggulan kompetitif dari lembaga pendidikan, dan dapat dievaluasi pada tiga tingkatan: mahasiswa, staf dan institusi. Selanjutnya Huang, Binney dan Hede (2010:5) menyatakan bahwa beberapa dimensi yang dapat digunakan untuk menilai kinerja lembaga pendidikan antara lain : kinerja mahasiswa, kinerja staf dan kinerja tingkat institusi. Kinerja pemasaran universitas biasanya diukur dari popularitas universitas berdasarkan pilihan para stakeholder, khususnya para pengguna lulusan/alumni. Dengan demikian konstruk penelitian kinerja Program Studi dalam penelitian ini merupakan sesuatu yang dihasilkan oleh program studi dalam periode tertentu dengan mengacu pada standar yang ditetapkan. yang meliputi: Input (target perolehan mahasiswa), proses (Lama Studi mahasiswa, hasil akreditasi), Output (kualitas lulusan/IPK), Impact (serapan lulusan). 


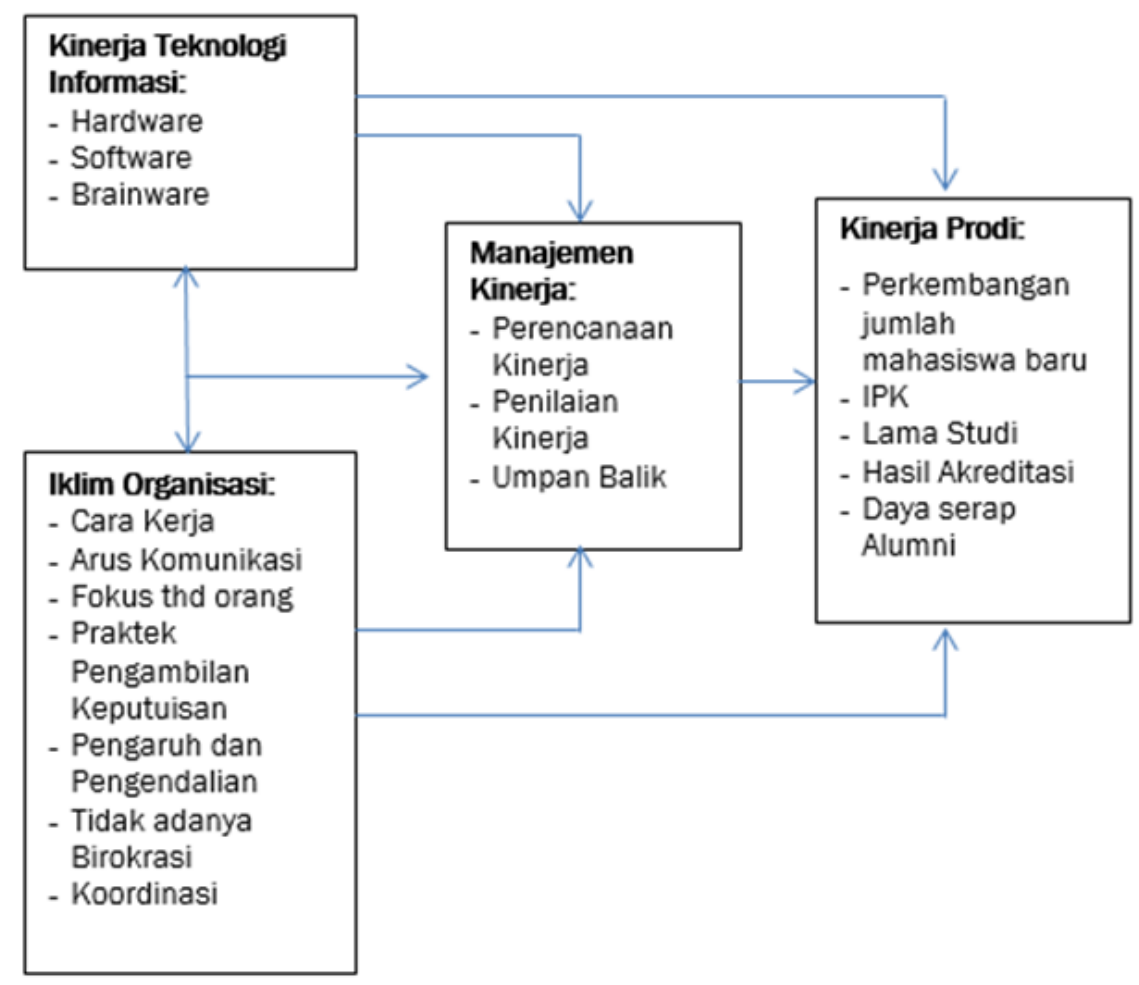

Gambar 1. Model Peningkatan Kinerja Program Studi melalui Manajemen Kinerja yang didukung oleh Pemanfaatan Teknologi Informasi dan Iklim Organisasi

\section{METODE}

Metode yang digunakan adalah deskriptif dan metode explanatory research, untuk menguji model kinerja program studi melalui manajemen kinerja yang didukung oleh pemanfaatan teknologi informasi dan iklim organisasi. Mengacu pada variabelvariabel penelitian di atas, maka penelitian ini dilakukan dengan menggunakan metode survai (Churchill and lacobucci, 2005:79).

Unit analisis dalam penelitian ini adalah program studi yang ada di UNIKOM, sedangkan unit observasinya adalah Ketua Program Studi sebagai penanggung jawab kinerja Prodi, para karyawan dan dosen terpilih di lingkungan masing-masing Prodi. Penelitian ini menggunakan sampel jenuh, dimana seluruh populasi sebagai sampel penelitian. Teknik analisis data menggunakan Partial Least Square SEM.

Pengujian validitas dengan menggunakan korelasi product moment. Butir pernyataan dinyatakan valid jika koefisien korelasinya $\geq$ 0,30 (Barker et al., 2002:70). Selanjutnya kuesioner yang sudah valid dilakukan pengujian reliabilitas menggunakan metode split-half dimana kuesioner dinyatakan reliable apabila koefisiennya $\geq 0,70$ (Barker et al., 2002:70). Kuesioner yang disebarkan untuk mengumpulkan data pada penelitian ini telah valid dan reliabel dengan hasil item pernyataan memiliki indeks validitas $\geq$ 0,30 dan reliabilitas $\geq 0,70$.

Analsisis Deskriptif

Menurut Cooper dan Schindler (2006;467) 
untuk data ordinal maupun data interval yang memiliki distribusi asimetris, ukuran pemusatan dapat dilakukan melalui distribusi rentang antar kuartil. Kuartil pertama persentil ke-25, kuartil kedua (median) persentil ke-50 dan kuartil ketiga persentil ke-75. Pada kuesioner yang menggunakan skala 1 sampai 5 maka kuartil pertama $=1-2$ kategori buruk $(<2)$, kuartil kedua $=2-3$ kategori kurang $(>=2)$, kuartil ketiga $=3-4$ kategori cukup $(>=3)$ dan kuartil keempat $=4-5$ kategori baik $(>=4)$.

\section{Pengujian Hipotesis}

\section{a. Hipotesis Pertama}

H0:ү1.1, $ү 1.2, \beta_{1.1}=0 \quad$ : Manajemen kinerja (n1) tidak dipengaruhi oleh pemanfaatan teknologi informasi (६1) dan iklim organisasi (६2)

H1:ү1.1, $ү 1.2, \beta_{1.1} \neq 0 \quad$ : Manajemen kinerja (n1) dipengaruhi oleh pemanfaatan teknologi informasi (६1) dan iklim organisasi (६2)

\section{b. Hipotesis Kedua}

\begin{tabular}{|c|c|}
\hline$H_{0}: Y_{1.1}, Y_{1.2}, \beta_{1.1}, \beta_{2.1}=0$ & $\begin{array}{l}\text { Kinerja program } \\
\left.\text { studi ( } \eta_{2}\right) \text { tidak } \\
\text { dipengaruhi } \\
\text { secara langsung } \\
\text { pemanfaatan } \\
\text { teknologi informasi } \\
(\xi 1) \quad \text { dan iklim } \\
\text { organisasi ( }(\xi 2) \\
\text { maupun tidak } \\
\text { langsung melalui } \\
\text { manajemen } \\
\text { kinerja }(n 1)\end{array}$ \\
\hline $.1, \mathrm{p} 2.1 \neq 0$ & $\begin{array}{lr}\text { : Kinerja } & \text { program } \\
\text { studi } & \left(n_{2}\right)\end{array}$ \\
\hline
\end{tabular}

\author{
dipengaruhi \\ secara langsung \\ pemanfaatan \\ teknologi informasi \\ (६1) dan iklim \\ organisasi \\ maupun tidak \\ langsung melalui \\ manajemen \\ kinerja $(n 1)$
}

Untuk Pengujian hipotesis parsial, menggunakan uji “t” dengan rumus:

$$
t=\frac{\hat{\gamma}_{3 i}}{S E\left(\hat{\gamma}_{3 i}\right)}
$$

\section{Pengujian Hipotesis Simultan menggunakan uji $\mathrm{F}$ dengan rumus:}

$$
F_{1}=\frac{R^{2} / k}{\left(1-R^{2}\right) /(n-k-1)}
$$

Kriteria uji:

Tolak hipotesis nol jika $F$ lebih besar dari nilai $\mathrm{F}$ tabel pada tingkat signifikansi $5 \%$ dan dengan derajat bebas pembilang $v_{1}=k$, dan derajat bebas penyebut $v_{2}=n-k-1$. Dengan $k$ adalah banyaknya variabel penyebab dan $\mathrm{n}$ adalah ukuran sampel.

\section{HASIL PENELITIAN DAN PEMBAHASAN}

Keberhasilan organisasi, dalam hal Universitas Komputer Indonesia bukan hanya tergantung pada bagaimana organisasi tersebut melaksanakan proses dan aktivitas kesehariannya semata, akan tetapi bagaimana kegiatan dan aktivitas rutin maupun kondisional diintegrasikan dalam seluruh komponen organisasi yang rawan konflik. Peningkatan efisiensi dan efektivitas yang mendorong ke arah inovasi memerlukan usaha-usaha yang terencana dengan baik dan terjamin keberlanjutannya untuk mempertajam arah dan 
meningkatkan kelayakan kegiatan, program, maupun kebijaksanaan dalam perspektif satu manajemen strategis (strategic management). Untuk itu penting melaksanakan penataan Program Studi di perguruan tinggi berdasarkan manajemen kinerja sehingga tercipta akuntabilitas perguruan tinggi.

Hasil analisis dalam penelitian ini dapat digambarkan dalam

gambar yang memperlihatkan pengaruh satu variabel terhadap variabel lain, berikut ini.

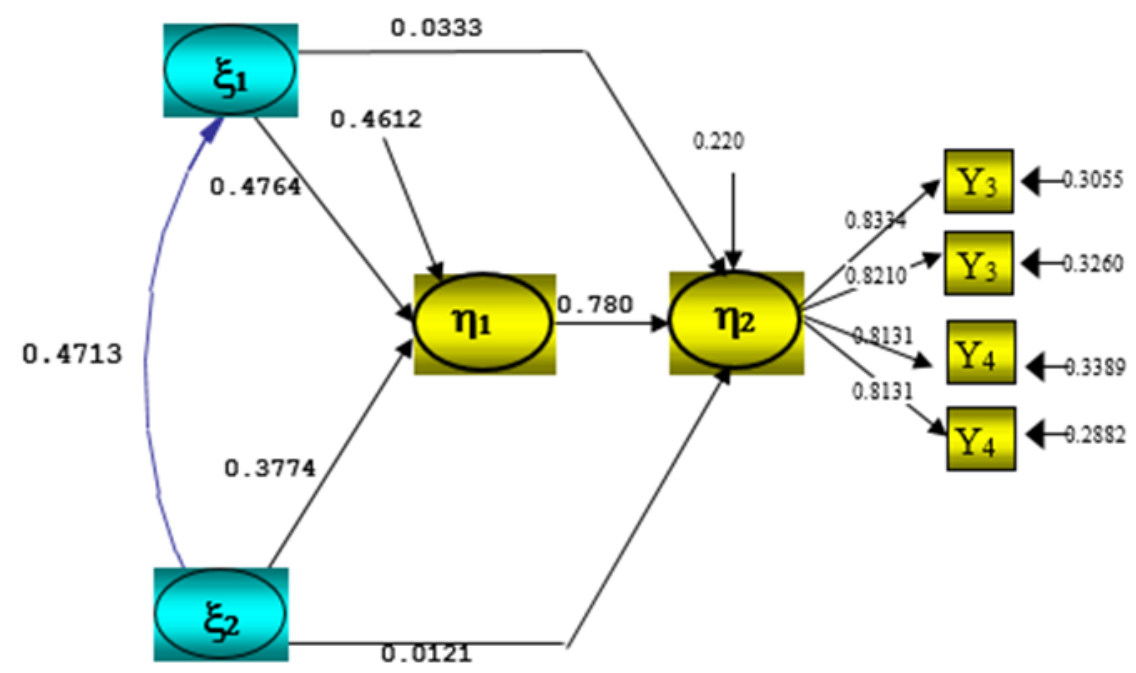

Gambar 2. Hasil Analisis Statistik Kinerja Program Studi sebagai dampak dari Manajemen Kinerja, Pemanfaatan Teknologi Informasi dan Iklim Organisasi

Berdasarkan gambar 1 dilihat dari besarnya koefisien jalur dapat dijelaskan sebagai berikut:

1. Pengaruh Kinerja teknologi informasi dan Iklim Organisasi terhadap Manajemen Kinerja menjelaskan adanya pengaruh yang termasuk dalam kategori cukup. Hasil penelitian ini mendukung hasil penelitian sebelumnya, walaupun yang menjadi unit analisisnya berbeda.

2. Kinerja Program Studi dipengaruhi oleh pemanfaatan teknologi informasi dan iklim organisasi, namun masing-masing pengaruhnya sangat rendah. Hasil penelitian ini kurang mendukung hasil penelitian sebelumnya yang menunjukkan adanya pengaruh yang cukup besar dari kinerja teknologi informasi, dan iklim organisasi terhadap kinerja organisasi.

3. Dampak sangat besar terhadap kinerja oprogram studi terwujud tidak hanya apabila UNIKOM mampu memanfaatkan teknologi informasi yang handal dan iklim organisasi yang kondusif, namun harus didukung oleh manajemen kinerja yang efektif. Dengan demikian dalam penelitian ini manajemen kinerja merupakan syarat mutlak yang diperlukan untuk mewujudkan kinerja organisasi yang optimal.

Berdasarkan penjelasan pada nomor 1 sampai dengan nomor 3 tersebut di atas, terlihat bahwa pencapaian kinerja program 
studi akan terwujud apabila UNIKOM mampu mengimplementasikan pemanfaatan teknologi informasi yang handal dan iklim organisasi yang kondusif, secara bersamaan, selanjutnya didukung oleh pembentukan manajemen kinerja yang efektif. Dengan demikian hasil penelitian ini dapat dikemukakan bahwa manajemen kinerja yang efektif mampu berperan sebagai faktor perantara yang menguatkan pengaruh pemanfaatan teknologi informasi dan iklim organisasi terhadap kinerja program studi (manajemen kinerja merupakan variabel intervening (full intervening).

Selanjutnya berdasarkan hasil penelitian dan pembahasan tersebut, dapat dijelaskan bahwa tinggi rendahnya kinerja Program Studi di UNIKOM tidak ditentukan secara langsung oleh pemanfaatan teknologi informasi dan iklim organisasi, melainkan harus didukung oleh manajemen kinerja yang efektif.

Melalui hasil penelitian ini, diharapkan memiliki kegunaan dan dapat dipertimbangkan untuk membantu menyusun langkah-langkah strategis pimpinan UNIKOM khsunya dan Perguruan Tinggi umumnya dalam upaya meningkatkan kinerja program studi melalui peningkatan pemanfaatan teknologi informasi yang lebih handal dan iklim organisasi yang kondusif serta didukung oleh manajemen kinerja yang efektif. Program manajemen kinerja pada dasarnya adalah sebuah proses dalam manjemen sumber daya manusia. Istilah "manajemen" dalam program tersebut mempunyai implikasi bahwa kegiatan tersebut harus dilaksanakan sebagai sebuah proses manajemen yang umum yang dimulai dengan penetapan tujuan dan sasaran dan diakhiri dengan evaluasi.

\section{KESIMPULAN}

Berdasarkan hasil analisis dan pembahasan, maka penelitian ini menghasilkan kesimpulan sebagai berikut:

1. Kinerja program studi belum sesuai dengan harapan pinstitusi UNIKOM, manajemen kinerja penerapannya belum terintegrasi antara perencanaan kinerja, penilaian kinerja dan umpan baliknya. Selanjutnya pemanfaatan teknolog informasi belum diimplementasikan secara tepat, dan untuk iklim organisasi sudah cukup kondusif dalam lingkungan UNIKOM.

2. Pemanfaatan teknologi informasi yang yang terintegrasi antara software, hardware dan brainware dengan iklim organisasi yang kondusif mampu membentuk manajemen kinerja yang efektif. Hal ini berarti manajemen kinerja menjadi efektif apabila didukung oleh pemanfaatan teknologi informasi yang handal dan dalam lingkungan iklim organisasi yang kondusif. Selanjutnya pemanfaatan teknologi informasi dan iklim organisasi belum mampu mewujudkan capaian kinerja program studi yang optimal.

3. Kinerja program studi dapat dicapai secara optimal melalui manajemen kinerja yang efektif yang didukung oleh pemanfaatan teknologi informasi yang handal dengan iklim organisasi yang kondusif. Dalam penelitian ini manajemen kinerja yang dominan dalam mewujudkan kinerja program studi. Artinya Kinerja program studi dapat diwujudkan secara optimal apabila program studi menerapkan manajemen kinerja yang efektif yang didukung oleh pemanfaatan teknologi informasi yang handal dan teritegrasi dengan iklim organisasi yang kondusif. 


\section{DAFTAR PUSTAKA}

Bagranoff, Nancy A. et al. 2010. Core Concepts of Accounting Information Systems, John Wiley\&Sons, Inc. 111 River Street, Hoboken, NJ 07030-5774. USA. Eleventh Edition.

Barker, Chris ;Nancy Pistrang \& Robert Elliot. 2002. Research Methods in Clinical Psychology. (2nd ed.). John Wiley \& Sons, LTD Chichester England

Churchill and lacobucci, 2005:79), Churchill. Gilbert A and lacobucci Dawn. 2005. Marketing Research: Methodological Foundation. Ninth Edition, Thomson South-Western.

Cooper, Donald R. \& Pamela S.Schindler. 2006. Business Research Methods". $9^{\text {th }}$ Ed. New York: McGraw Hill Companies.Inc.Mc.Kinsey \& Co, (2000:4),

Dadang Munandar (2015). Implementation of Marketing Communication In Order To Build Institution Image (A Case Study At Study Program Providing Advantage Scholarship), International Journal of Applied Business and Economic Research, Vol. 14. 217-222.

Denison, Daniel R. 1990. Corporate Culture and Organizational Effectiveness. Canada: John Wiley \& Sons Inc. p. 25, 43

Dessler, Gary. 2013. Human Resource Management. England: Pearson Educated Limited. p. 30.

Eddy Soeryanto. Tren Kepemimpinan Wirausahaan dan Manajemen Inovatif. Andy Offset. Yogyakarta. 2016

Greaves, C., P. Kipling, and T.D. Wilson. 1999, Business Use of the World Wide Web with Particular Reference to UK Companies, International Journal of Information Management, Vol. 19:449-470.

Hoogendoorn, 1999, Economic Development, Harper Collins College Publishers, Inc., USA.

Huang, H., Binney, W., \& Hede, A. M. (2010). Strategic marketing of educational institutions. Australia New Zealand Marketing Academy Conference.

Komariah,A, dan Triatna, C. 2005. Visionary Leadership Menuju Sekolah Efektif. Jakarta: Bumi Aksara.

Lederer, A.L., D.A. Mirchandani, and K. Sims, 2001, The Search for Strategic Advantage from the World Wide Web, International Journal of Electronic Commerce, Vol.5, No.4:117-133.

Mahn Hee Yoon, Sharon E. Beatty dan Jaebeom Suh ( 2001), The Effect Of Work Climate on Critical Employee and Customer Outcomes, An Employee Level Analysis, International Journal of Service Industry Management, (C)MCB University Press 0956-4233, Vol 12, No 5, 2001, pp. 500-521, ,

Mangkunegara, A. Prabu, 2004, Manajemen Sumber Daya Manusia Perusahaan, PT. Remaja Rosda Karya, Bandung.

Mathis,Robert L., \& John H. Jackson. 2004. Human Resource Management. International Student Edition. SouthWestern, a division of Thomson Learning, Thomson Learning is a trademark used herein under license, In Singapore.

O'Brien, James A., and Marakas, George M. 2009. Management Information Systems. Ninth Edition.New York: McGraw-Hill/Irwin.

Plunkett, Warren R.; Raymond F. Attner; 
Gemmy S. Allen. 2005. Management: Meeting and Exceeding Customer Expectation. Thomson Corporation. p. 212, 313, 546, 550, 558, 577-578.

Simamora, Henry, 2004, Manajemen Sumber Daya Manusia, edisi ke tiga, Penerbit STIE YKPN, Yogyakarta.

Turban, Efraim \& Linda Volinino (2011): Information Technology For Management: Improving Strategic and Operational Performance. 8 th edition, USA: John Willey \& Sons
Weill $P$ and Broadbent, 1998, Improving Business and Information Strategy Aligment: Learning From The Banking Industry, IBM System Journal, Vol 32, No. 1, 162-179.

Wirawan. 2007. Budaya dan Iklim Organisasi, Teori Aplikasi dan Penelitian. Penerbit: Salemba Empat. p.121, 131. 